\title{
The Development of Science and Technology Councils for Members of Congress
}

\author{
Lisbet T. Finseth $^{1,3}$, Lindsay K. Milliken ${ }^{2}$, Tricia White $^{2}$, \\ Michael A. Fisher $^{2}$ \\ ${ }^{1}$ University of Colorado, Anschutz Medical Campus, Cell and Developmental Biology, Aurora, CO \\ ${ }^{2}$ The Federation of American Scientists, Washington, DC \\ ${ }^{3}$ The National Science Policy Network, San Francisco, CA \\ https://doi.org/10.38126/ISPG190103
}

Corresponding authors: Lisbet.Finseth@CUAnschutz.edu and mfisher@fas.org

Keywords: Congress; science council; science and technology; science policy; technical assistance; science and technology policy; S\&T policy

\begin{abstract}
Executive Summary: Policy decisions should be informed by science, but legislators and their teams have limited capacity to connect with evidence-based resources and the expert community. By strengthening ties between science and policy, these two domains can be more readily integrated when making policy decisions. We established a process for building science and technology councils for Members of Congress, which function as a platform for scientists and legislators to engage. Legislators were selected by gauging the potential for objective, nonpartisan information from scientists to inform their work, as well as their offices' prioritization of science policy issues. Experts with deep knowledge of these scientific issues were vetted, recruited, and appointed to the councils, and Members of Congress were connected to their designated councils. This bridging of science and policy demonstrates a platform that scientists can utilize to communicate objective, policy-relevant research and analysis as a trusted source of information, leading to more scientifically informed policy decision-making.
\end{abstract}

\section{Introduction}

Science and policy influence one another. Scientific research can produce useful data, identify societal problems, develop solutions, and measure the effectiveness of legislation. The use of science for lawmaking is known as "science for policy" (Brooks 1964; White 2011). Moreover, most scientific disciplines are impacted by government policymaking, also known as "policy for science." Each year, Congress allocates funding to many federal science agencies, such as the National Institutes of Health (NIH), the National Science Foundation (NSF), and the National Aeronautics and Space Administration (NASA), among others, to support research across the United States. The results of this federally funded research ideally inform the policymaking process. Some examples of issues that are impacted by both science for policy and policy for science include radioactive waste management, climate change, biodiversity, healthcare, and the management of infectious diseases such as COVID-19 (Cash et al. 2003; Corey et al. 2020; Görg et al. 2016; Madhavan et al. 2021; Nuclear Energy Agency, Disposal of radioactive waste: forming of a new approach in Germany: summary and international perspective, in: FSC Workshop Proceedings, Hitzacker and Hamburg, Germany 2006; Van Den Hove 2007).

When scientific research is not incorporated into policy decision-making, those decisions may misdiagnose the problem, formulate inadequate solutions, or fail to recognize future consequences, resulting in ineffective legislation (Belei 2019; 
Lewallen, Theriault, and Jones 2016; Warner 2019). This omission is not always on purpose. In most cases, lawmakers must handle policy issues related to multifaceted and nuanced scientific topics, and their offices often lack sufficient scientific resources to fully parse these topics(Science 1998; Science and Technology Policy Assessment: A Congressionally Directed Review 2019; Miesen 2019). For example, when the Senate Judiciary Committee drafted the Compliance with Court Orders Act of 2016 - a bill designed to disable end-to-end encryption on mobile devices for easier access for law enforcement - it received a wide range of criticism from the science and technology community due to the bill's misconception of cybersecurity (Warner 2019). Furthermore, the circulation of misinformation, such as during the COVID-19 pandemic, can further contribute to inadequate policy decisions (Lewandowsky, Ecker, and Cook 2017), such as weak social distancing policies during the initial spread of SARS-CoV-2 (Siedner et al. 2020). These examples demonstrate the need to efficiently integrate science-derived knowledge into the policymaking process.

As science and technology (S\&T) become a larger part of everyday life, there is an increasing necessity to bridge the domains of science and policy; however, these realms function quite differently. Fundamental scientific research is driven by curiosity of the unknown, and results are verified through incremental steps to build consensus. This lengthy process requires acknowledging limitations and unidentified factors. Policy is typically a response to societal issues driven by the values of political parties, legislators, stakeholders, and elected officials' constituents (Bradshaw and Borchers 2000). Unlike scientific research, policy is developed through compromise within a fast-changing environment (Akerlof 2018). These differences can serve to complicate the communication and collaboration of scientists and legislators.

Establishing and implementing methods to improve communication between scientists and policymakers can help inform legislators on major issues and better anticipate the consequences of policy decisions (Akerlof 2018). This paper describes how the Federation of American Scientists (FAS) has developed a model for launching tailored expert councils that provide S\&T information and resources to Members of Congress. Using the model, we established a science council for a Member of Congress composed of eight experts on policy-relevant S\&T topics. These volunteer experts were recruited from both nationally recognized research institutions and local institutions near the Member's district. The experts serve as a direct connection between the legislator and the S\&T community, facilitating a proactive dialogue about important scientific and policy issues.

\section{Background}

The US Congress relies on several internal and external resources for "science for policy" and "policy for science." Demand for policy-relevant S\&T information has only increased over the past few decades, and these existing resources have limited capacity to serve legislators and their teams. More experts in the S\&T community should mobilize to augment existing resources by providing Congress with up-to-date research and analysis relevant to pressing policy issues. This section details how Congress and its S\&T resources are structured, as well as how scientists can take action to meet legislative branch S\&T needs.

\section{i. Government S\&T Institutions}

The United States Congress consists of the House of Representatives and the Senate (US Const. art. I, § 1-3). Its main function is to pass legislation. When Members of Congress want to change federal law, the Members and their staff draft and introduce a bill. The bill is referred to the congressional committees that have jurisdiction over the issues targeted by the bill. Committee members gather information about the bill's provisions, make amendments, debate the changes, and vote on the newest version.

When a bill is passed by the relevant committees, it can be brought to the floor to be voted on by the full House or Senate. After a bill's passage, it is delivered to the other congressional chamber and put through a similar process with that chamber's committees. After a bill is passed by both the House and the Senate, a conference committee is formed that 
includes both House and Senate members. The goal of conference is to reconcile any differences between the two versions of the bill. Once all the provisions have been agreed upon by the conference committee, identical versions of the bill must pass through both House and Senate again before it can be presented to the President to sign or veto (US Const. art. I, § 7).

The congressional committees are crucial to the legislative process, as they are a key avenue for experts to provide scientific information to Congress. Congress has over forty committees and 150 subcommittees. Members are assigned based on their interests, expertise, seniority, and ability to influence policy within that jurisdiction (White 2011). Multiple committees discuss policy related to science or have jurisdiction over scientific institutions. For instance, the Senate Energy and Natural Resources Committee has broad jurisdiction, legislating on issues like renewable energy, climate change, and water, and the House Committee on Science, Space, and Technology has jurisdiction over the National Science Foundation (NSF), National Aeronautics and Space Administration (NASA), National Institute of Standards and Technology (NIST), and the White House Office of Science and Technology Policy (OSTP).

\section{ii. S\&T Support for Members of Congress}

Although legislators are expected to understand, debate, and amend all legislation that passes through Congress, many lawmakers do not specialize in science, technology, engineering, and mathematics. During the $116^{\text {th }}$ US Congress, out of 435 House seats, only about six percent of the seats were filled by Members with scientific backgrounds: thirteen physicians, five scientists, and ten engineers (Membership of the 116th Congress: A Profile 2020). The Senate, which has 100 members, only contains five Members with expertise in science: three physicians, an optometrist, and an engineer. Most of the Members of Congress have credentials in either law, business, or political science (Membership of the 116th Congress: A Profile 2020).

Although few lawmakers have scientific backgrounds, seventy percent recognize the value of incorporating science into legislation (Akerlof 2018). Legislators also acknowledge they are not the ideal candidates for assessing technical legislation, with sixty percent stating that they need a scientific advisor (Akerlof 2018). However, the internal resources available to legislators that provide scientific expertise do not have enough capacity to satisfy all S\&T needs. The current nonpartisan S\&T resources available to Members of Congress include the Government Accountability Office (GAO) Science, Technology Assessment, and Analytics team (STAA) and the Congressional Research Service (CRS). Congress used to have an organization specifically dedicated to educating Members about scientific issues called the Office of Technology Assessment (OTA). OTA was established by the Office of Technology Assessment Act of 1972 (P.L. 92-484) (The Technology Assessment Act 1972) and it was active until 1995, at which point its funding was eliminated. Although the OTA still exists in statute, it remains inactive because Congress has not allocated any funding to relaunch its activities, despite several efforts to re-fund it. After the closure of the OTA, GAO attempted to compensate by providing scientific reports on federal programs through the STAA (Consolidated Appropriations Act 2008; Report of Committee Activities 2002). GAO's mission is to investigate how taxpayer dollars are spent and equip the Legislative Branch and federal agencies with evidence-based information that assists the entire government in saving money and working more efficiently, and so its resources are focused broadly across federal government activities. CRS is housed in the Library of Congress and publishes policy analyses on a wide range of issues in response to congressional requests (Legislative Reorganization Act 1970). CRS mainly provides in-depth research into many different policy issues, and drafting reports takes a significant amount of time. These reports are also mostly focused on the policy aspects of specific issues, rather than scientific research. As requests for information have increased, the researchers have not had enough capacity to address all congressional S\&T inquiries.

Because congressional S\&T resources are stretched so thin, legislators rely heavily on non-governmental institutions to fill information gaps. External resources such as think tanks, lobbyists, and partisan political advisors act as sources of policy advice, but 
some can be more opinion-based, or lack comprehensive knowledge on a subject (Craft and Howlett 2017, 2012; Nelson and Yackee 2012; OECD 2007). In addition, outside groups might be advocating for a particular policy that aligns with their mission, and not necessarily serving the interests of elected officials' constituents. Boundary organizations that bridge the scientific and political domains, such as FAS, or the Health Effects Institute (HEI), can provide a transfer of nonpartisan, objective knowledge by creating stable systems in which long-term relationships between science and policy are facilitated (Guston 2001). These organizations develop opportunities and incentives for scientific and political systems to engage while being a distinct boundary for each side to maintain a non-partisan, fact-based relationship without the risk of violating lobbying rules and regulations. The impact of these intermediary institutions is directly dependent on the proximity to the decision-maker (Craft and Howlett 2012; Sarewitz and Pielke 2007). Proximity to legislators that facilitates communication - via either geography or strong, trusted relationships increases the influence of the information system on policy decisions (Craft and Howlett 2012). Consistent, trusted relationships with legislators, like those which are maintained by boundary organizations, are a key facet to contributing to policy development.

Non-government systems are key pathways connecting science with policy, increasingly leveraged to satisfy legislators' demands for information. Tailored science councils constitute one of the ways boundary organizations can foster communication between scientists and lawmakers.

\section{iii. Approach}

Science councils can provide highly targeted policy-relevant S\&T information to legislators and their staff, helping to close the knowledge gap between science and policy, foster deeper connections between Members of Congress and the S\&T community, and more effectively communicate science to policymakers. Once established, the councils will:
- Establish a link between the S\&T knowledge available in research institutions and legislative offices,

- Allow scientists to raise emerging science and technology matters with legislators, and gauge legislators' key priorities, and

- Nurture experts' ability to provide information on emerging national S\&T issues.

Councils, made of volunteer experts from the scientific community, are unique to each congressional office and provide S\&T information and resources by gauging a legislator's priorities. These councils are designed to relay relevant, timely information with minimal jargon. Volunteer experts are required to play a non-partisan, objective, educational role, able to relay scientific concepts in a concise, digestible manner, and are vetted for these qualities. FAS serves as a 'hosting' boundary organization that facilitates relationships and establishes platforms for communication for each council and legislative office.

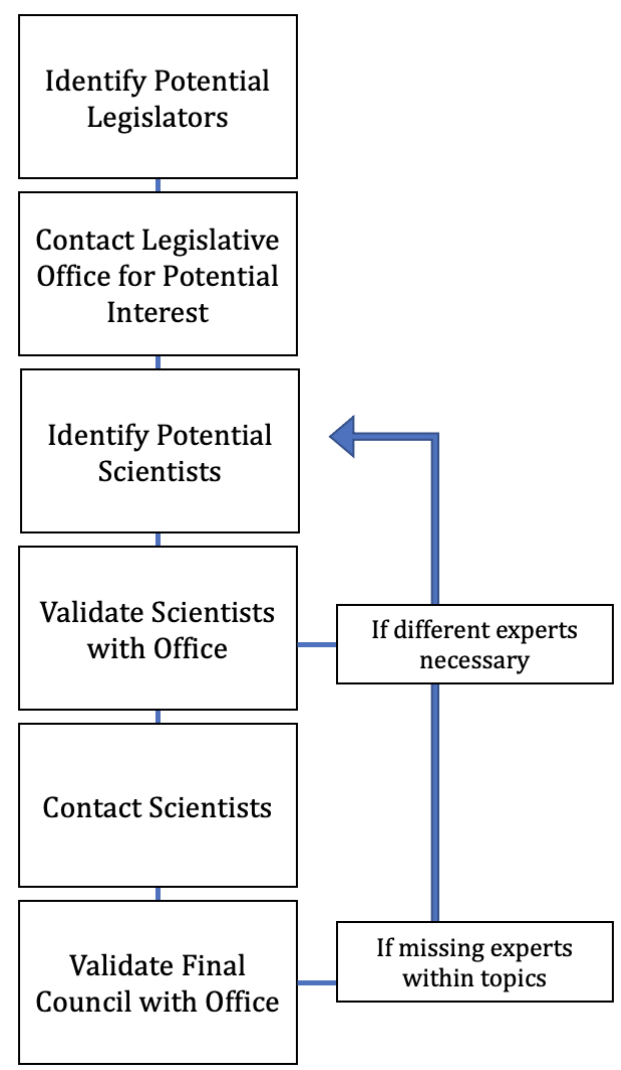

Figure 1: Process for creating councils. 


\section{S\&T Council Development}

To create a tailored science council, we developed a process which is illustrated in Figure 1. Each Member of Congress we reached out to was selected based on their past legislative activity, speeches, social media activity, and campaign statements on scientific issues. These identifiers were used to gauge their interest in having a science council formed for them. We contacted a select group of lawmakers' offices and conducted introductory meetings with our points of contact to explain our process for forming a science council. These meetings were also helpful in identifying policy issues their Members of Congress considered priorities, and likely interested in learning more about. Potential council members were then vetted for expertise in the Member of Congress' topics of interest, and rosters of experts were relayed back to the legislative offices. We iterated on the rosters to achieve the right blend of expertise. Experts were contacted for interest in volunteer positions within councils and finalized council members were verified with offices. All personal information about the Members of Congress and experts were withheld from this report for privacy.

\section{i. Identifying legislative interest}

We identified Members of Congress who may be interested in having a science council based on their interest in scientific topics, their professional and educational backgrounds, and their policymaking needs for their congressional committee appointments. For example, Members of Congress who sit on the House Committee on Science, Space, \& Technology study, edit, and debate almost all the S\&T bills for their chamber. During this process, they often need to connect with expertise in the scientific community, and so some of these Members were targeted for outreach.

\section{ii. Contacting legislative offices}

After identifying a Member of Congress who may be interested in having a science council, we email their staffers, such as the legislative director, deputy chief of staff, and legislative aides responsible for S\&T issues. We reach out to their staff because Members of Congress have an immense workload and must rely heavily on their staff to assist in many parts of the policymaking process (Pontius 2003; Fox 1977).

Our emails briefly introduced FAS, the science council project, and how we tailor the science council to the Member's priorities. We suggested an initial meeting to explain our model further. Because staffers are very busy, we would re-engage with our points of contact on a weekly or biweekly cadence. All aides that responded to initial emails agreed to online meetings of thirty minutes to discuss the concept of an S\&T council. An example email can be found in the Appendix.

During our meetings with the staff, we suggested potential scientific areas of focus for a council based on the Member's legislative background and expertise, the characteristics of their district, and the most pressing national issues. For example, if the legislator released a commentary on the impact of wildfires on their district, forestry management and fire mitigation were suggested as potential areas of focus for their science council.

\section{iii. Identifying and contacting council members}

Scientific experts were researched and contacted based on their research specialty, location (ideally within the Member of Congress's district or state), their ability to communicate scientific topics clearly, and non-partisan online presence. For our most recent council efforts, experts specialized in physical sciences, biological sciences, earth and environmental sciences, public and human health, engineering, computer science and technology, and social and behavioral sciences. These experts had a mixture of highly specialized expertise (e.g., proteins contributing to neuronal degradation in amyotrophic lateral sclerosis (ALS)) or more generalized backgrounds within science and technology (e.g., artificial intelligence (AI)). We shared initial lists of experts with our points of contact in the Member of Congress' office. Once a roster was approved, we emailed the prospective members of the science council to assess their interest in joining. We briefly interviewed each prospective council member to discuss the role of the council in expanding the S\&T capacity of Congress, and the expectations and 
responsibilities of being a member. These expectations include:

- Attending quarterly meetings with the Member of Congress;

- Providing objective, non-partisan information on scientific issues relating to their expertise; and

- Contributing to the crafting of informative written products which could be shared with not only the Member of Congress they are engaging with directly, but also with other Members who are interested in the same topics.

Members of the council were chosen to be reflective of the general demographics of the state and hold either a professorship or academic research association at a state or private institution. To address issues within the community as well as across the US, experts specializing in each topic of interest represented both the legislator's district and the national level (e.g., two local experts and two national experts on energy). Diversity and inclusion were key considerations during the formation of each council; it was critical to invite women and people of color to participate.

\section{iv. Coordinating communication}

During the initial meeting, S\&T councils were expected to discuss recent developments in each of their fields and respond to questions asked by the Member of Congress. They were asked to act as a representative of their field while also communicating relevant scientific implications for pressing policy issues related to their disciplines. Experts were also encouraged to tap into their professional networks to maximize the council's ability to provide the best scientific information to the Member of Congress. In consultation with the Member of Congress and their team, we determined that a quarterly meeting cadence was appropriate for the Member's needs and the schedule constraints of staff and the science council experts. Due to the COVID-19 pandemic, online platforms, such as Zoom (Zoom Video Communications, Inc.), were used throughout the development of councils. We had originally planned to organize in-person meetings with the Members of Congress, but given the convenience of video conferencing, we have concluded that a majority of our future meetings will be virtual. Periodic in-person meetings to further build the relationship between the experts and the Member of Congress will be considered as the councils develop further.

\section{Council Formation}

Results from the initial contact of legislative offices through the full formation of councils are illustrated in Figure 2. Sixteen Members of Congress were chosen for potential contact (five Senators, eleven Representatives). From this list, the offices of ten Representatives and three Senators were emailed regarding the formation of S\&T councils. Only one Senate office agreed to meet but declined the further development of a council due to "lack of current necessity." Six Representatives' offices agreed to initial meetings, totaling four Democrats and two Republicans. From these discussions, only one Democrat fully declined a council. One Republican Representative's office was provided a roster of experts in space policy but declined further curation of a council. Two Democrats declined full councils but were still provided scientific support. One of these two Democrats was provided a roster of experts within ALS for a potential briefing but asked to follow up at a later point. The other Democrat was provided written testimonials of the impacts of the COVID-19 pandemic on the progression of scientific research. Testimonials were collected from five researchers and submitted to the legislative office. Although transient, these steps toward full councils allowed the identification of scientists willing and able to discuss their research with politicians. These experts can be contacted in the future if there are future opportunities for them to serve as a science resource, and new legislators have learned FAS is a dependable boundary organization.

Two Representatives, one from each political party, decided to move ahead with the full formation of S\&T councils. Deeper into the process, the Republican Representative then decided against forming a council. The Democratic Representative was provided with rosters of experts knowledgeable in the issue areas of COVID-19, climate, US leadership in S\&T, AI, and social science. Experts were selected based on 


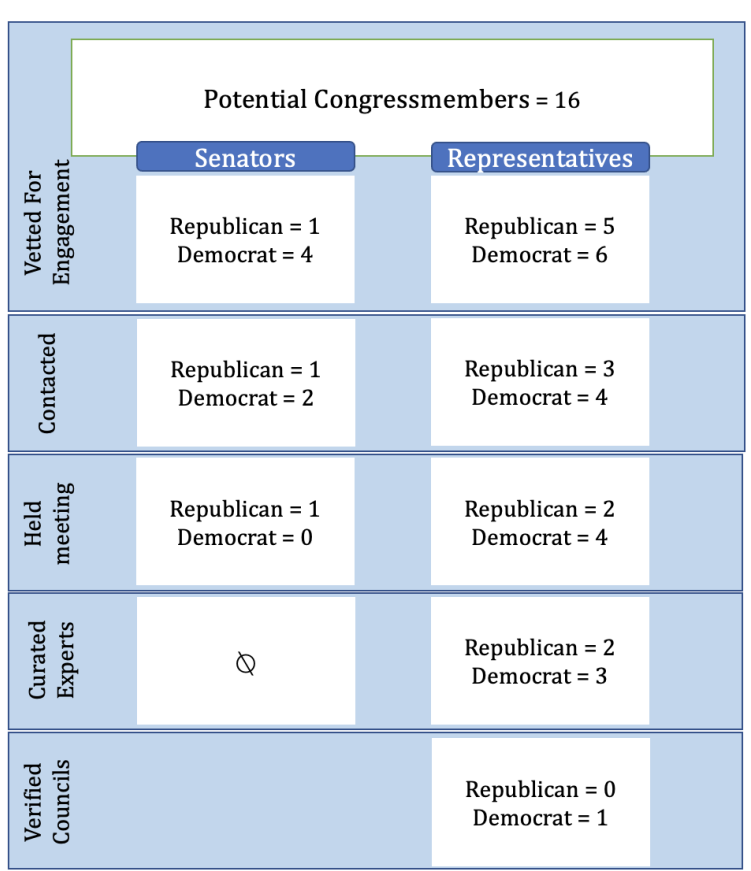

Figure 2: Legislative response \& interest. Number of legislators, including congressional position and party affiliation, engaged at each step of forming councils. specialization, local versus national association, and communication capabilities (see Methods). Two rosters were created covering multiple aspects of each topic (Table 1).

After sign-off from the legislative office, a total of fifteen scientists within Table 1 were either invited or interviewed. Scientists from Roster 1 were initially contacted for the volunteer positions. Five scientists either did not respond or declined the position. To fill the council, experts from Roster 2 were then selected and contacted. Of Roster 2, two scientists declined, and four scientists accepted, resulting in eight experts on the S\&T council. Six were located within the Representative's district or state (i.e., local), and three experts were from across the US (i.e., national).

\begin{tabular}{|c|c|c|c|c|c|c|}
\hline & \multicolumn{3}{|c|}{ Roster 1} & \multicolumn{3}{|c|}{ Roster 2} \\
\hline S\&T Topics & $\begin{array}{l}\text { Specialization } \\
\text { *contacted }\end{array}$ & $\begin{array}{l}\text { Local vs } \\
\text { National }\end{array}$ & $\begin{array}{l}\text { Council } \\
\text { Member }\end{array}$ & $\begin{array}{l}\text { Specialization } \\
\text { *contacted }\end{array}$ & $\begin{array}{l}\text { Local vs } \\
\text { National }\end{array}$ & $\begin{array}{l}\text { Council } \\
\text { Member }\end{array}$ \\
\hline \multirow[t]{3}{*}{ COVID-19 } & Immunology* & Local & $\mathrm{X}$ & $\begin{array}{l}\text { Mitigating the } \\
\text { effects of COVID on } \\
\text { social, emotional \& } \\
\text { physical health with } \\
\text { technology }\end{array}$ & National & \\
\hline & $\begin{array}{l}\text { Outbreak response } \\
\text { and medical } \\
\text { countermeasures* }\end{array}$ & National & $X$ & $\begin{array}{l}\text { Public health } \\
\text { preparedness, } \\
\text { pandemics }\end{array}$ & National & \\
\hline & $\begin{array}{l}\text { Vaccine } \\
\text { development and } \\
\text { neglected tropical } \\
\text { diseases* }\end{array}$ & National & & $\begin{array}{l}\text { Social epidemiology, } \\
\text { social environments } \\
\text { effects on health* }\end{array}$ & Local & $X$ \\
\hline Climate & $\begin{array}{l}\text { Global \& regional } \\
\text { modeling of } \\
\text { aerosols* }\end{array}$ & Local & $\mathrm{X}$ & $\begin{array}{l}\text { Earth/atmosphere } \\
\text { interactions, } \\
\text { oceanography, } \\
\text { atmospheric } \\
\text { dynamics* }\end{array}$ & National & $X$ \\
\hline
\end{tabular}




\begin{tabular}{|c|c|c|c|c|c|c|}
\hline & $\begin{array}{l}\text { Climate modeling } \\
\text { and temperature } \\
\text { changes* }\end{array}$ & National & & $\begin{array}{l}\text { Emergence of } \\
\text { complex social and } \\
\text { biological systems }\end{array}$ & Local & \\
\hline \multirow[t]{4}{*}{$S \& T$} & $\begin{array}{l}\text { Advanced nuclear } \\
\text { reactors, AI for } \\
\text { reactor modeling }\end{array}$ & Local & & $\begin{array}{l}\text { Documents and } \\
\text { reports for particle } \\
\text { physics* }\end{array}$ & Local & \\
\hline & $\begin{array}{l}\text { Cybersecurity and } \\
\text { networking* }\end{array}$ & Local & & $\begin{array}{l}\text { Internet of Things, } \\
\text { wireless networks }\end{array}$ & Local & \\
\hline & $\begin{array}{l}\text { Molecular } \\
\text { mechanisms for } \\
\text { intercellular } \\
\text { communication* }\end{array}$ & National & & $\begin{array}{l}\text { Synthetic cells to } \\
\text { perform different } \\
\text { jobs }\end{array}$ & National & \\
\hline & & & & $\begin{array}{l}\text { Movement control } \\
\text { of materials across } \\
\text { bio membranes* }\end{array}$ & Local & $\mathrm{X}$ \\
\hline$A I$ & $\begin{array}{l}\text { AI applications for } \\
\text { business* }\end{array}$ & Local & $\mathrm{X}$ & $\begin{array}{l}\text { Cognitively inspired } \\
\mathrm{AI} \text {, machine } \\
\text { learning, computer } \\
\text { vision* }\end{array}$ & National & $\mathrm{X}$ \\
\hline \multirow[t]{2}{*}{$\begin{array}{l}\text { Social } \\
\text { Science }\end{array}$} & $\begin{array}{l}\text { Social networks, } \\
\text { urban } \\
\text { neighborhoods, } \\
\text { gun violence, } \\
\text { policing* }\end{array}$ & Local & $X$ & $\begin{array}{l}\text { Cultural } \\
\text { competency, } \\
\text { support for African } \\
\text { American } \\
\text { undergraduates* }\end{array}$ & Local & \\
\hline & $\begin{array}{l}\text { Social Justice, } \\
\text { vocational } \\
\text { psychology, and } \\
\text { racial/ethnic } \\
\text { identity* }\end{array}$ & Local & & & & \\
\hline
\end{tabular}

Table 1: S\&T experts and specialization for the Democratic Representative. ' $X$ ' designates the individual as a final council member

\section{Discussion}

The council members' areas of expertise reflected the Member of Congress' priorities and major national policy issues. As COVID-19 is a current national concern that affects the daily life of every American, there is great need for experts on this topic (Table 1). Other topics were more diverse and demonstrated

the wide range of issues each legislator addresses. As these councils are meant to provide information on the most relevant S\&T topics of the day, the composition of the councils may change over time. For example, if the COVID-19 pandemic diminishes in significance, composition could shift toward a topic with more pressing policy needs. This flexibility allows councils to maintain value for the legislator.

There are various reasons why Members of Congress might be cautious to form an official council. First, some of the contacted Members of Congress have been well-established as supporters of science. These legislators likely already have trusted scientific 
relationships and might feel a council is not needed. Second, given the novelty of the project, a trusted relationship with FAS had not yet been created for many offices. Legislators and their staff rely heavily on trust and vetting unfamiliar sources for dependability can be time-consuming and difficult. By providing an intermediate step of one-time resources, such as ALS experts for a briefing, FAS can begin to build trust with new legislators and demonstrate the value of S\&T resources. Even though most legislators did not fully engage with the project, they became aware of FAS as a boundary organization for scientific knowledge, potentially allowing the development of relationships for future work. One opportunity for growth is to focus on outreach to new legislators ("freshmen"). These new Members are less likely to have many strong connections to the scientific community. Therefore, they might be in greater need of a council and more responsive to the development of one.

There were other challenges in developing S\&T councils that should be taken into consideration as this project continues. First, although offices generally provided an initial response, multiple emails were usually required for further engagement. Second, legislators and their staff are generalists due to the large volume of policy issues they are required to address. Most legislative staffers handle numerous, disparate policy issues that could be as wide-ranging as "defense and healthcare" or "renewable energy and space science," and many offices' S\&T policy priorities are somewhat broad. As researchers are quite specialized, the research that would be most relevant to the current state of politics had to be surfaced. For instance, specialists in COVID-19 could provide information on numerous topics including the molecular biology and function of the SARS-CoV-2 virus, the spread of infectious disease through a population, vaccine development, hospital capacities, public health preparedness, and many other areas. Therefore, providing legislators with expertise that fits their priorities and multiple rosters of scientists with descriptions of their specialties allowed tailored engagement. Lastly, legislators highly value interactions and communication with their constituents to address local concerns (Dodson et al. 2013). However, some districts have only a small handful of research organizations or institutions of higher education. This lack of local nonprofit scientific resources could be addressed by vetting experts from private industries.

During our process of identifying and gathering experts for councils, scientists declined for multiple reasons. Of the seven scientists that declined the offered council position for the Democratic Representative, three did not respond to initial emails. One expert declined as they were not a good fit; one expert declined due to time constraints and limited capacity to engage; and two experts declined because their institutions did not approve the position. This demonstrates many of the hindrances that scientists describe in attempting to engage in science communication and science policy. Science is a time-constraining profession which limits researchers' capacity to engage, and a general lack of institutional support further inhibits these endeavors (Gerald G. Singh et al. 2014; G. G. Singh et al. 2019; Survey of factors affecting science communication by scientists and engineers 2006).

Further incentives such as coverage of travel expenses when in-person meetings resume, or enhanced prestige and recognition awarded for serving on a council could be developed to assess whether these would increase participation of researchers. Lastly, multiple aspects contribute to a researcher's capacity to engage, such as communication training, public engagement skill development, and institutional support. FAS relied on vetting experts with previous science communication experiences, and future programs could offer communication and policy short courses to experts, which would promote effective communication to legislators and potentially increase connections with policy. Colleges and universities could also incorporate engagement with policymakers into their decision-making processes for promotion and tenure, further incentivizing academic experts to participate in initiatives such as science councils.

\section{Conclusion}

Legislators have only limited capacity to engage with S\&T information (Science and Technology Policy 
Assessment: A Congressionally Directed Review 2019). Through the development of S\&T councils, we demonstrate the capabilities of boundary organizations, such as FAS, to fulfill the demand for scientific information and provide a link between science and policy (Guston 2001). While in their infancy, these councils still demonstrate that there are scientists and legislators eager to engage but lacking platforms and support for collaboration.
More legislators are being contacted to increase the number of councils and further deduce to what capacity researchers can provide support to legislators. By enabling communication for the discussion of S\&T policy-relevant topics, the proximity between scientists and legislators is increased, furthering the integration of science into policy decision-making.

Appendix A: A template for initial contact with congressional staffers

"Dear [Legislative Director] and [Legislative Aide],

My name is Lisbet Finseth, I am a Neuroscientist at the University of Colorado Anschutz. I'm working with the Federation of American Scientists (FAS) to establish a science and technology resource for Members of Congress. If possible, we would love 20 minutes of your time to discuss this project with you and determine if it would be of interest to Representative/Senator [].

We are working to connect [state] science and technology experts with Members of Congress. These scientists would be an entirely unique resource and focus on issues prioritized by the Member. Such issues could include the most updated information from mental health resources for veterans, or wildfire and forest management, or satellite infrastructure.

By gauging your office's priorities, we would work with you to curate experts from [state] research institutions, private businesses and nonprofits such as [].

If possible, I'd like to discuss the potential of this resource for Representative/Senator [ ]. Please let me know if you have any questions.

Thank you"

\section{References}

Akerlof, K. 2018. Congress's use of science: Considerations for science organizations in promoting the use of evidence in policy. American Association for the Advancement of Science (Washington, DC).

Belei, B., Toni Bush, Maeve Campbell, Ash Carter, Lucy Chase, Mignon Clyburn, Bennett Craig, Daniel Gastfriend, Dipayan Ghosh, Gene Kimmelman, Heidi Legg, Laura Manley, Nicco Mele, Hong Qu, Amy Robbinson, Phillip Verveer, and Tom Wheeler. 2019. Big Tech and Democracy: The critical role of congress. Belfer center for science and international affairs, Harvard Kennedy School.
Bradshaw, G. A. and Jeffrey G. Borchers. 2000.

"Uncertainty as information: Narrowing the science-policy gap." Conservation Ecology 4, no. 1 (1). https://doi.org/10.5751/ES-00174-040107

Brooks, H. 1964. "The scientific advisor." In Scientists and national policy-making, 73-96. New York, NY: Columbia University Press.

Cash, D. W., William C. Clark, Frank Alcock, Nancy M. Dickson, Noelle Eckley, David H. Guston, Jill Jager, and Ronald B. Mitchell. 2003. "Knowledge systems for sustainable development." Proceedings of the National Academy of the United States of America 100 (14): 8086-91. https://doi.org/10.1073/pnas.1231332100 
Consolidated Appropriations Act. 110-161. 110, Dec. 26, 2007.

Corey, L., John R. Mascola, Anthony S. Fauci, and Francis S. Collins. 2020. "A strategic approach to COVID-19 vaccine R\&D." Science 368 (6494): 948-950. https://doi.org/10.1126/science.abc5312

Craft, Jonathan and Michael Howlett. 2012. "Policy formulation, governance shifts and policy influence: location and content in policy advisory systems." Journal of Public Policy 32 (2): 79-98.

https://doi.org/10.1017/s0143814x12000 $\underline{049}$.

Craft, Jonathan and Michael Howlett. 2017. "The dual dynamics of policy advisory systems: The impact of externalization and politicization on policy advice." Policy and Society 32 (3): 187-197. https://doi.org/10.1016/i.polsoc.2013.07.0 $\underline{01}$.

Dodson, E. A., Katherine A. Stamatakis, Stephanie Chalifour, Debra Haire-Joshu, Timothy McBride, and Ross Brownson. 2013. "State legislators' work on public health-related issues: what influences priorities?" Journal of Public Health Management \& Practice 19 (1): 25-9. https://doi.org/10.1097/PHH.0b013e3182 46475c.

Fox, Harrison W. Jr. and Susan Webb Hammond. 1977. "Congressional Staffs: The Invisible Force in American Lawmaking." New York: The Free Press 439, no. 227 (1): 174-175. https://doi.org/10.1177/00027162784390 $\underline{0139}$.

Görg, Christoph, Heidi Wittmer, Caitriona Carter, Esther Turnhout, Marie Vandewalle, Stefan Schindler, Barbara Livorell and Alexandra Lux. 2016. "Governance options for science-policy interfaces on biodiversity and ecosystem services: comparing a network versus a platform approach." Biodiversity and Conservation 25 (7): 1235-1252. https://doi.org/10.1007/s10531-016-1132 $\underline{-8}$.
Guston, D. H. 2001. "Boundary organizations in environmental policy and science: An introduction." Science Technology \& Human Values 26 (4): 399-408.

https://doi.org/10.1177/01622439010260 $\underline{0401}$

Legislative Reorganization Act. 91-510. Oct. 26. Lewallen, Jonathan, Sean M. Theriault and Bryan D. Jones. 2016. "Congressional dysfunction: An information processing perspective." Regulation \& Governance 10 (2): 179-190. https://doi.org/10.1111/rego.12090.

Lewandowsky, Stephan, Ullrich K. H. Ecker and John Cook. 2017. "Beyond Misinformation: Understanding and Coping with the "Post-Truth" Era." Journal of Applied Research in Memory and Cognition 6 (4): 353-369. https://doi.org/10.1016/i.jarmac.2017.07.0 $\underline{08}$.

Madhavan, S., Lisa Bastarache, Jeffrey S. Brown, Atul J. Butte, David A. Dorr, Peter J. Embi, Charles P. Friedman, Kevin B. Johnson, Jason H. Moore, Isaac S. Kohane, et al. 2021. "Use of electronic health records to support a public health response to the COVID-19 pandemic in the United States: a perspective from 15 academic medical centers." Journal of the American Medical Informatics ASsociation 28 (2): 393-401.

https://doi.org/10.1093/jamia/ocaa287.

Membership of the 116th Congress: A Profile. 2020. edited by Congressional Research Service.

Miesen, M., Laura Manley, Maeve Cambell, Chris Kuang and Emily Roseman. 2019. Building a 21st Century Congress: Improving Congress's Science and Technology Expertise. Belfer Center for Science and International Affairs, Harvard Kennedy School. https://www.belfercenter.org/publication/ building-21st-century-congress-improvingcongresss-science-and-technology-expertise \#toc-7-0-0

Nelson, D., and S. W. Yackee. 2012. "Lobbying Coalitions and Government Policy Change: An Analysis of Federal Agency Rulemaking." Journal of Politics 74 (2): 339-353. 
https://doi.org/10.1017/S0022381611001 $\underline{599}$.

Nuclear Energy Agency, Disposal of radioactive waste: forming of a new approach in Germany: summary and international perspective, in: FSC Workshop Proceedings, Hitzacker and Hamburg, Germany. 2006. Paris: OECD Publishing.

OECD. 2007. "Political advisers and civil servants in European countries." Sigma Papers 38. https://doi.org/10.1787/5kml60qnxrkc-en.

Pontius, John S. and Faye M Bullock. 2003. Congressional Staff: Duties and Functions. Congressional Research Service. http://www.llsdc.org/attachments/wysiwy g/544/CRS-98-340.pdf.

Report of Committee Activities. 2002.

Sarewitz, Daniel and Roger A. Pielke. 2007. "The neglected heart of science policy: reconciling supply of and demand for science." Environmental Science \& Policy 10 (1): 5-16. https://doi.org/10.1016/j.envsci.2006.10.0 $\underline{01}$.

Science and Technology Policy Assessment: A Congressionally Directed Review. 2019. edited by National Academy of Public Administration Congressional Research Service.

Science, House Committee on. 24 September 1998. Unlocking Our Future Toward a New National Science Policy: A Report to Congress. http://www.house.gov/science/science_pol icy report.htm.

Siedner, Mark J., Guy Harling, Zahra Reynolds, Rebecca F. Gilbert, Sebastien Haneuse, Atheendar S. Venkataramani and Alexander C. Tsai. 2020. "Social distancing to slow the US COVID-19 epidemic: Longitudinal pretest-posttest comparison group study." PLoS Med 17 (8): e1003244. https://doi.org/10.1371/journal.pmed.100 $\underline{3244}$.
Singh, Gerald G., Vinicius F. Farjalla, Bing Chen, Andrew E. Pelling Elvan Ceyhan, Martin Dominik, Eva Alisic, Jeremy Kerr, Noelle E.

Selin, Ghada Bassioni, et al. 2019. "Researcher engagement in policy deemed societally beneficial yet unrewarded." Front Ecol Environ 17 (7): 375-382. https://doi.org/10.1002/fee.2084. Singh, Gerald G., Jordan Tam, Thomas D. Sisk, Sarah C. Klain, Megan E. Mach, Rebecca G. Martone and Kai M. A. Chan. 2014. "A more social science: barriers and incentives for scientists engaging in policy." Frontiers in Ecology and the Environment 12 (3): 161-166. https://doi.org/10.1890/130011.

Survey of factors affecting science communication by scientists and engineers. 2006. Royal Society (London, UK: Royal Society). https://royalsociety.org/-/media/Royal_Soc iety Content/policy/publications/2006/11 11111395.pdf.

The Technology Assessment Act. 92-484. Oct. 13. Van Den Hove, Sybille. 2007. "A rationale for science-policy interfaces." Futures 39 (7): 807-826.

https://doi.org/10.1016/i.futures.2006.12. 004.

Warner, Justin. and Grant Tudor. 2019. The Congressional Futures Office: A Modern Model for Science \& Technology Expertise in Congress. Belfer Center for Science and International Affairs, Harvard Kennedy School. https://www.belfercenter.org/sites/default /files/2019-06/PAE/CongressionalFutures Office.pdf.

White, Kasey Shewey and Joanne P. Carney. 2011. Working with Congress: A Scientist's Guide to Policy. The American Association for the Advancement of Science.

Lisbet Finseth recently earned her Master of Science in Biomedical Sciences and Biotechnology from the University of Colorado, Anschutz Medical Campus. In addition, she studies oligodendrocytes and myelination in the Macklin lab. She was the President of the science communication and policy group, Project Bridge 
Colorado. Lisbet was also co-chair for the Western Hub of the National Science Policy Network, and a SciPol Scholar-in-Residence, collaborating with the Federation of American Scientists. She received her BA from Luther College.

Lindsay Milliken is a Policy Analyst for Science, Technology, and Innovation Policy at the Federation of American Scientists. She supports both the Congressional Science Policy Initiative and the Technology and Innovation Initiative. Previously, she worked as a Legislative Research Assistant at Lewis-Burke Associates, a government relations firm specializing in science policy and higher education. Lindsay received her BA in Political Science with a minor in Physics from American University in Washington, DC.

Tricia White is an Intern with the Federation of American Scientists. She supports both the Congressional Science Policy Initiative and the Biological Weapons Convention Project. Tricia obtained her BA in International Affairs from the University of Georgia and is a MA candidate in Nonproliferation and Terrorism Studies at the Middlebury Institute of International Studies.

Michael A. Fisher, PhD, is a senior fellow with the Federation of American Scientists, working on a range of issues across the science and technology policy landscape. He leads the Congressional Science Policy Initiative, writes for the FAS Science Policy Blog and other outlets, contributes to the Day One Project, and serves on the SciTech Forefront Advisory Board. He also served as a field director with a congressional campaign and has experience with informal STEM education and the development of public-private partnerships. Dr. Fisher earned his B.S. in Biology from The College of New Jersey and his Ph.D. in Molecular Biology from Princeton University.

\section{Acknowledgements}

This work was funded by the Gordon and Betty Moore Foundation and the William and Flora Hewlett Foundation. LTF received funding from the National Science Policy Network. 